\title{
A note on terminology: bilingualism, plurilingualism and plurilingual intercultural competence or are we all plurilingual?
}

\section{[K pojmosloviu bilinvizmu, plurilingvizmu a viacjazycnej interkulturnej kompetencii alebo sme vsetci viacjazycni?]}

\author{
Jana Birova - Monika Barancova - Zuzana Simkova
}

\section{DOI: 10.18355/XL.2016.09.02.114-127}

\begin{abstract}
Anotácia
$\mathrm{V}$ príspevku sa zaoberáme terminológiou $\mathrm{v}$ oblasti bilingvizmu, viacjazyčnosti. Ciel’om štúdie je poukázat' na diachronický vývoj slova bilingvizmus a vznik neologizmov plurilingvizmus, multilingvizmus a viacjazyčná interkultúrna kompetencia ako aj vývin významov týchto termínov. Na záver štúdie autori predstavujú sebahodnotiacu škálu vlastnej viacjazyčnej interkultúrnej kompetencie, ktorú predstavila na národnej prednáške J. Bírová a ktorá musí byt' ešte vedecky zrevidovaná, aby našla úplné uplatnenie v spoločenskej praxi.

Kl'účové slová: bilingvizmus, plurilingvizmus, multilingvizmus, viacjazyčná interkultúrna kompetencia, sebahodnotiaca škála
\end{abstract}

Pojem bilingvizmus, dvojjazyčnost' vyvoláva pozornost' lingvistov už od začiatku minulého storočia. Rok 1928 sa tradične označuje ako začiatok výskumov zaoberajúcich sa bilingvizmom. V tomto roku sa konala konferencia $\mathrm{v}$ Luxemburgu, kde sa viac menej oficiálne začína výskum tohto nového prúdu. Medzi prvé práce, ktoré sa zaoberajú bilingvizmom patrili diela Jespersena (1922), Pintera a Kellera (1922), Saera (1923), Leopolda (1939) a najväčší rozvoj vo výskume môžeme pozorovat' $\mathrm{v}$ druhej polovici dvadsiateho storočia.

Termín bilingvizmus J. M. Sanchez Carrion používa ako ekvivalent termínu multilingvizmus alebo mnohojazyčnost', to znamená, že označuje všeobecný jav, ktorý zahíňa všetky situácie používania dvoch alebo viacerých jazykov tou istou osobou alebo skupinou (Sanchez Carrion, 1974: 7). Termín bilingvizmus je v odbornej literatúre chápaný odlišne. Za bilingvistu býva rozličnými autormi označovaný každý, kto sa pohybuje na stupnici, ktorej jeden koniec predstavujú jednotlivci, ktorí ovládajú oba jazyky na úrovni monolingvistov a druhý koniec je zastúpený jednotlivcami, ktorí druhý jazyk ovládajú pasívne. L. Bloomfield (1933: 56) za bilingvizmus považuje „schopnost' ovládat' dva jazyky na úrovni rodeného hovoriaceho“, čiže inými slovami, schopnost' hovorit' dvomi jazykmi rovnako ako materinským jazykom. Bilingválna osoba však nie je súčtom dvoch monolingvistov. Dva jazyky, ktoré táto osoba ovláda nikdy nie sú na rovnakej úrovni. Jeden jazyk má vždy tendenciu špecializovat' sa na isté vybrané oblasti a d'alší zasa na iné. Aj stupeň plynulosti v obidvoch jazykoch býva rozdielny. Preto by sa podl'a tejto definície za bilingvistu nemohol považovat' takmer nikto.

U. Weinreich (1979 [1953]: 1) ho definuje ako ,alternatívne používanie dvoch alebo viacerých jazykov“. J. MacNamara predostiera úplne inú definíciu. Za bilingválnu osobu považuje takú, ktorá disponuje aspoň minimálnou kompetenciou $\mathrm{v}$ inom ako materinskom jazyku v najmenej $\mathrm{v}$ jednej zo štyroch základných jazykových zručností, t. j. porozumenie, hovorenie, čítanie a písanie (1967: 56 - 60).

$\mathrm{V}$ definíciách iných autorov sa ako dôležitý znak bilingvizmu zdôrazňuje pravidelnost' v používaní dvoch alebo viacerých jazykov. Takto ho definuje napr. F. 
Grosjean (1982: 1): „Bilingvizmus je pravidelné používanie dvoch alebo viacerých jazykov.“

J. Štefánik (2000) bilingvizmus definuje ako „schopnost’ alternatívneho používania dvoch alebo viacerých jazykov pri komunikácii s ostatnými v závislosti od situácie a prostredia, v ktorom sa táto komunikácia uskutočňuje“. Je to viacrozmerný jav: deskriptívno-lingvistický, psycholingvistický, kognitívno-lingvistický i sociolingvistický.

Všetky tieto definície pohybujúce sa v rozmedzí od aspoň minimálnej schopnosti vyjadrovania sa $\mathrm{v}$ inom ako materinskom jazyku až po úplnú znalost' tohto jazyka však predstavujú určité nezrovnalosti. V zhode s tvrdením M. Etxebarria Arostegui (2002: 29-30) ich považujeme za málo účinné, ked’že nedostatočne upresňujú, čo sa rozumie pod pojmom „kompetencia rodeného hovoriaceho“ a podobne ani pod pojmom „minimálna jazyková kompetencia v druhom jazyku“. Základný problém týchto definící je, že sa sústredia iba na jeden rozmer toho javu, a to poznat' jazykové kompetencie hovoriaceho v oboch jazykoch, pričom sa zabúda na d’alšie rozmery toho javu. Súhlasíme s definíciou bilingvizmu ako ju chápu M. Siguan a W. Mackey (1986: 17): „Osoba, ktorá má okrem svojho vlastného jazyka podobné schopnosti v inom jazyku a ktorá je schopná použivat' jeden alebo druhý jazyk za všetkých okolností s rovnakou účinnost'ou.“Aj ked' môžeme konštatovat', že ide o opis ideálnej situácie, ked’že v reálnom živote ide o osoby, ktoré sa iba viac alebo menej prispôsobujú tomuto ideálu.

\section{Individuálny bilingvizmus}

Pri základnom rozdelení bilingvizmu rozdel’ujeme individuálny a spoločenský bilingvizmus. Pojem individuálny bilingvizmus sa vzt'ahuje na jedinca, ktorý okrem jazyka okolitej spoločnosti používa ešte iný jazyk. A to bud' iba on sám alebo ide o bilingválnu rodinu či bilingválnu menšinu (Morgensternova et al., 2011: 29).

Podl'a J. Stefanika (2000: 16-17) je individuálny bilingvizmus nevyhnutným dôsledkom spoločenského bilingvizmu a bez neho nemôže existovat'. Existencia individuálneho bilingvizmu však ešte nemusí nevyhnutne viest' ku vzniku spoločenského bilingvizmu.

M. Etxebarria Arostegui (2002: 30-32) tvrdí, že medzi základné znaky, ktoré konštituujú základný charakter individuálneho bilingvizmu, patria:

- autonómia kódov, čiže nezávislost' a oddelené udržiavanie oboch kódov, aj ked' nie vždy je úplná, pretože v určitých momentoch každá bilingválna osoba pri používaní jazyka A vsúva prvky (fonetické, sémantické alebo syntaktické) jazyka B a naopak;

- $\quad$ alternácia kódov alebo prechádzanie z jedného kódu do druhého, ktorá zvykne nastat', ak dve osoby, ktoré hovoria jazykom A, ale poznajú aj jazyk B, automaticky prejdú k používaniu jazyka B v momente, ak sa do konverzácie pripojí d’alšia osoba, ktorá pozná len tento jazyk;

- preklad, čiže schopnost' vyjadrit' tie isté významové obsahy $\mathrm{v}$ dvoch jazykových systémoch. Aj ked' nemôžeme povedat', že všetky významy vyjadritel’né v jazyku A alebo v jazyku B majú byt' spoločné.

V literatúre venovanej bilingvizmu sa okrem základného členenia spomínajú aj iné druhy bilingvizmu. Predstaví sa typológia spracovaná podl'a J. Stefanika (2000: $11-21)$, M. Morgensternovej et al. (2011: 28-32) a M. Etxbarria Arostegui (2002: 32-35). 
- Koordinovaný bilingvizmus, jednotlivec disponuje dvoma funkčne nezávislými jazykovými systémami a zložený bilingvizmus, ked' má nositel' pre dve jazykové formy jeden spoločný jazykový obsah, ktorý je splynutím dvoch pôvodných.

- Vyvážený bilingvizmus, ked' sa obidva jazyky vyvíjajú alebo sú vyvinuté úplne rovnomerne, čo je vel'mi vzácny a skôr nedosiahnutel'ný ideál a dominantný bilingvizmus, ked' jeden z jazykov prevláda.

- Infantný bilingvizmus, čiže simultánne osvojenie dvoch jazykov hned' od narodenia, detský bilingvizmus predpokladá sukcesívne osvojenie dvoch jazykov, t. j. diet’a si po osvojení prvého jazyka osvojí druhý jazyk v škôlke alebo v prvých ročníkoch základnej školy. Pri adolescentnom bilingvizme prebieha osvojenie druhého jazyka medzi $10-11$ až približne $16-17$ rokom. Neskoršie osvojenie si druhého jazyka prebieha pri dospelom bilingvizme.

- Simultánny bilingvizmus, ked' si deti osvojujú dva jazyky od narodenia a sukcesívny bilingvizmus, ked' k osvojovaniu druhého jazyka dochádza až po získaní istých jazykových kompetencií v prvom jazyku.

- Prirodzený bilingvizmus sa rozvíja v prirodzenom bilingválnom prostredí domova alebo dlhým pobytom $\mathrm{v}$ inojazyčnej krajine, umelý bilingvizmus sa rozvíja, ked' sa jednotlivec učí druhý jazyk formálnou systematickou výučbou, napr. v škole.

- Produktívny bilingvizmus, ked' jednotlivec nielen rozumie ale aj hovorí, píše a číta obidvoma jazykmi a receptivny bilingvizmus, ked' je človek schopný rozumiet' druhému jazyku bud' v jeho písanej alebo zvukovej podobe.

- Bikultúrny bilingvizmus, ked' sa osoba pozitívnym spôsobom identifikuje s obidvomi kultúrami a monokultúrny bilingvizmus, ked' sa identifikuje len s jednou kultúrou týchto dvoch jazykov.

- Aditívny bilingvizmus, ked' sú v okolí, v ktorom bilingválny jednotlivec vyrastá, obidva jazyky spoločnost'ou rovnako hodnotené a subtraktívny bilingvizmus, ked' je sociokultúrny kontext taký, že jeho materinský jazyk je znehodnocovaný.

Subtraktívny bilingvizmus sa $\mathrm{v}$ priebehu vzdelávacieho procesu definuje ako protikladná kategória $\mathrm{k}$ aditívnemu bilingvizmu. $\mathrm{V}$ porovnaní $\mathrm{s}$ aditívnym, subtraktívny bilingvizmus poukazuje na situáciu, ked' sa žiak učí druhý jazyk na úkor prvého jazyka a to najmä v prípade, že materinským jazykom je menšinový jazyk. V tomto prípade ovládanie prvého jazyka klesá, zatial' čo ovládanie d’alšieho jazyka sa zvyšuje.

Posledné dva pojmy boli vytvorené W. E. Lambertom (1983), kanadským výskumníkom, ktorý je nazývaný "otcom“ bilingválneho výskumu. Subtraktívny bilingvizmus charakterizuje ako stratu alebo narušenie rodného jazyka a kultúry. V európskom kontexte takáto situácia nastáva, ked' menšinový jazyk žiaka je vytlačený spoločensky silnejším a dominantným jazykom ako napríklad angličtinou. (Lambert, 1983: 100). Rodný jazyk a kultúra sú potlačené, zatial' čo väčšinový a dominantný jazyk je posilnený. V prípade výskytu subtraktívneho bilingvizmu dané dva jazyky medzi sebou „sútažia“ namiesto vzájomného dopíňania sa (Liddicoat, 1991). V subtraktívnom dvojjazyčnom prostredí je rodný jazyk nahradený druhým jazykom, ktorý spôsobuje interferenciu vedúcu k problémom, s ktorými sa stretávajú už deti v predškolskom veku. Tam, kde rodný jazyk je napríklad jazyk taliansky a objaví sa subtraktívny prístup $\mathrm{k}$ rozvoju jazykov, prvý jazyk je nahradený dominantným jazykom a skôr negatívne ako pozitívne efekty sú spozorované v používaní daných dvoch jazykov. Ak sa $\mathrm{v}$ procese osvojovania druhého jazyka objaví negatívna 
interferencia, môže to mat' výrazný vplyv na žiakov materinský jazyk - problémy v procese osvojovania si cudzieho jazyka.

\section{Spoločenský bilingvizmus}

V spoločnosti rozšírený bilingvizmus jednotlivcov s ohl'adom na zastúpenie a funkciu dvoch jazykov nazýva M. Siguan spoločenským bilingvizmom. Uvádza, že „hovoríme o bilingválnej spoločnosti alebo o bilingválnej oblasti, ked’ sa v tej istej spoločnosti alebo medzi obyvatel'mi toho istého územia ako komunikačný prostriedok používajú zvyčajne dva rozdielne jazyky“ (1976: 27). Z tohto vyplýva, že ide hlavne o individuálnych dvojjazyčných jednotlivcov a bilingválna spoločnost' je až výsledkom akumulácie týchto jednotlivcov. Podl'a autora by bilingvizmus ako spoločenský jav mohol považovat' súčet bilingválnych jednotlivcov (ibid.: 28). Treba však poznamenat', že osoby sa nestávajú bilingválnymi sami od seba, ale preto, že potrebujú alebo chcú komunikovat's osobami, ktoré hovoria iným jazykom ako oni, či už v ich bezprostrednom rodinnom okolí alebo v iných oblastiach spoločnosti, v ktorých sa pohybujú (Etxebarria Arostegui, 2002: 43).

R. Appel a P. Muysken vo svojej práci Language Contact and Bilingualism (2005: 1-2) vyjadrujú, že ak sa v spoločnosti používajú dva alebo viac jazykov, hovoríme o bilingválnej spoločnosti. V tomto zmysle by takmer všetky spoločnosti mohli byt' považované za bilingválne. Jednotlivé spoločnosti sa však odlišujú formou a stupňom, akým sa v nich bilingvizmus prejavuje. Rozlišujú tri základné typy spoločenského bilingvizmu:

V situácii I sú obidva jazyky používané dvomi rozličnými skupinami a každá z týchto skupín je monolingválna. Medzi nimi sa nachádza niekol'ko bilingválnych jednotlivcov, ktorí sprostredkovávajú komunikáciu medzi týmito dvoma skupinami. V spoločnosti druhého typu sú všetci jednotlivci bilingválni a v tret’om type sa nachádzajú dve skupiny: jedna monolingválna a druhá bilingválna. Monolingválna skupina z tohto tretieho typu tvorí vo vel'a prípadoch minoritu, aj ked' nie vždy v zmysle počtu, ale skôr zo sociologického hl'adiska a zvykne byt' utláčanou.

Pojem diglosia súvisí s predmetom nášho terminologického výskumu. Termín diglosia prvýkrát v anglickej literatúre použil C. A. Fergusson (1959) na vyjadrenie situácie, ked' dve variety (tzv. vysoká a nízka) jedného jazyka existujú vedl'a seba v rámci jednej komunity. Každá z nich plní inú funkciu pri dorozumievaní a ich prekrývanie alebo miešanie je minimálne (Stefanik, 2000: 11). V slovenskej odbornej literatúre sa tento termín používa na charakteristiku existencie a striedavého používania dialektov a spisovného jazyka, resp. rôznych foriem slovenského jazyka. J. Stefanik (ibid.) vidí základný rozdiel medzi bilingvizmom a diglosiou v tom, že ,pri bilingvizme ide o dva rozdielne jazyky a pri diglosii o dve formy jedného jazyka. Výber a použitie jednej $\mathrm{z}$ dvoch foriem jazyka je pri diglosii určený jednoznačne funkčným kritériom“. Ayora Esteban (2008) prišla k záveru, že sa nachádzame v diglosnej jazykovej situácii, „ked’ sa vytvorí nerovnováha v prospech jedného z nich“. Diglosia je tiež podla niektorých jazykovedcov pokladaná za špecifický typ bilingvizmu.

W. Mackey (1962) definuje bilingvizmus ako schopnost' používat' viac ako jeden jazyk, a podl'a E. Haugena (1953) bilingvizmus je schopnost', ked' daná osoba je schopná viest' komplexné a zmysluplné rozhovory v inom jazyku. Jednotliví lingvisti a výskumní pracovníci majú iný názor na bilingvizmus a jeho definíciu a diferenciáciu. Ak chceme analyzovat’ termín „bilingválny“ do detailov, musíme sa spýtat' a pokúsit' sa nájst' odpovede na nasledujúce otázky: 
1. Je bilingvizmus meraný podl'a toho, ako plynule l'udia komunikujú v dvoch jazykoch?

2. Sú bilingválni jedinci iba tí, ktorí majú rovnakú komunikačnú schopnost' v oboch jazykoch?

3. Je osoba, ktorá nehovorí druhým jazykom plynule, ale pravidelne používa daný jazyk, bilingválna?

4. Je bilingválna osoba, taká, ktorá chápe druhý jazyk perfektne, ale nie je schopná komunikácie? Môže byt' daná osoba považovaná za bilingválnu, ak vie používat' dané jazyky, ale nemá rozvinutú kompetenciu písania?

5. Je bilingvizmus iba termín, ktorým samých seba l'udia označujú? Je osoba bilingválna, napriek tomu, že ovláda cudzie jazyky, ale má zábrany používat' dané jazyky v komunikácii?

6. Môže sa $\mathrm{z}$ bilingválnej osoby stat' monolingválna osoba $\mathrm{v}$ prípade zabudnutia druhého jazyka (Baker - Prys, 1998)?

\section{Plurilingvizmus a multilingvizmus}

Ked’že viacerí autori ako napríklad V. Janíková (2015) definujú rozlične rozdiely medzi týmito dvoma termínmi, autori zaoberajúci sa bilingvizmom a plurilingvizmom, píšci pre Radu Európy, rozhodli vo svojich publikáciách o štandardizácii termínov. Termín plurilingvizmus (aj plurilingvalizmus alebo viacjazyčnost') je definovaný ako používanie viacerých jazykov jednotlivcom. Ide o osobnostnú črtu, ktorá sa prejavuje v akcii komunikačnej situácie. Plurilingvizmus je potrebné chápat' ako stav resp. výsledok procesu osvojovania si/ učenia sa jazykov (Bernaus et al., 2007). Je chápaný $\mathrm{v}$ kontexte plurikulturalizmu. Jazyk je nielen významným aspektom kultúry, ale aj prostriedkom ku kultúrnym prejavom. Rozlišovat' je možné plurilingvizmus od multilingvizmu (viacjazyčnost' od mnohojazyčnosti), primárny plurilingvizmus od sekundárneho plurilingvizmu, simultánny od sukcesívneho. Multilingvizmus sa líši od plurilingvizmu - predstavuje znalost' viacerých jazykov resp. koexistenciu rôznych jazykov v danej spoločnosti (SERR, 2006). Je používaný na opis celkovej situácie (región, štát, obec) jazykového kontaktu. Opisuje kontexty, v ktorých sú jazyky v kontakte. Referuje výlučne k skupine, k skupinám, ktoré hovoria viacerými jazykmi (Trujillo, 2005).

\section{Viacjazyčná interkultúrna kompetencia}

Okrem opisu a definícíi stavov plurilingvizmu a multilingvizmu sa vo frankofónnej Európe, ale aj anglicky hovoriacimi definoval v poslednom období termín, ktorý sa taktiež vzt’ahuje k stavu jednotlivca v oblasti budovania jazykového a kultúrneho povedomia. Tento stav dostal po viacerých vedeckých analýzach (predtým predefinovaná ako plurilingválna plurikultúrna kompetencia, viacjazyčná interkultúrna kompetencia, pluralistická kompetencia) pomenovanie viacjazyčná interkultúrna kompetencia.

Pod termínom viacjazyčná interkultúrna kompetencia sa rozumie schopnost' používat' jazyk pre účely komunikácie a schopnost' zúčastnit' sa interkultúrnej interakcie, kde osoba je chápaná ako spoločenský aktér, ktorý má vedomosti z niekol'kých jazykov na rôznych stupňoch a skúsenosti s viacerými kultúrami (SERR, 2006). Rozlišuje sa, nakol'ko jednotlivec jazyky ovláda a nakol'ko ich používa. Každá rečová schopnost' môže byt' u jednotlivca rozvinutá v inej miere. Jeden jazyk má tendenciu byt' silnejší a býva nazývaný dominantným jazykom. Viacjazyčná interkultúrna kompetencia (Candelier et al., 2011: 13) je závislá od situácie, do ktorej sú vsadené komplexné socializačné úlohy. Vyžaduje od účastníkov komunikácie do istej miery aj nadobudnutie adaptačnej kompetencie, ktorá mobilizuje interné zdroje 
týkajúce sa schopností (savoir-faire), všeobecných, ale najmä nadobudnutých jazykových vedomostí (savoirs), existenciálnej kompetencie - osobnostných postojov (savoir-être) s externými prostriedkami (napríklad slovníky a iné prostriedky, stratégie). Viacjazyčná interkultúrna kompetencia je dynamická, evolutívna. Konfigurácia kompetencie sa vyvíja podl'a situačnej a komunikačnej trajektórie komunikanta - obohacuje sa o nové komponenty, alebo ich dopĺn̆a, či transformuje, respektíve niektorými inými komponentmi mrhá. Profil jazykových schopností sa môže líšit' z jedného jazyka do iného (napr. vynikajúce znalosti v ústnej komunikácii $\mathrm{v}$ dvoch jazykoch, ale dobré písanie vjednom, ovládanie tretieho jazyka iba v porozumení). Multikultúrny profil môže mat'inú konfiguráciu ako viacjazyčný profil (napr. dobrá znalost' určitého kultúrneho spoločenstva, ktorého jazyk jednotlivec do híbky nepozná alebo len málo poznatkov o kultúrnej komunite, ktorej jazyk ovláda výborne). Kvôli tejto nerovnováhe sa viacjazyčná interkultúrna kompetencia tiež vyznačuje tým, že $\mathrm{v}$ komunikácii sa stratégie používané na dosiahnutie rozličných ciel'ov v spoločnosti môžu líšit'. Napríklad postoje, v ktorých bude používatel' jazyka vediet' zdôrazňovat' otvorenost', prívetivost' a ochotu (a to cez gestá, mimiku, proxemiku), môžu v jazyku, ktorý neovláda dostatočne, kompenzovat' tento relatívny nedostatok, zatial' čo v jazyku, ktorý lepšie ovláda, môže ten istý jednotlivec v komunikácii pôsobit' vzdialenejšie alebo rezervovane (SERR, 2006). Táto pluralitná kompetencia (Coste, Moore, Zarate, 2009) slúži na vybudovanie jazykovo-kultúrnej identity, preto nejde o jednoduché pridanie viacerých kompetencií, ale o umožnenie kombinovat' a striedat' jazykové kódy. Ide o existenciu jednej pluralitnej (kompozitnej a heterogénnej kompetencie), ktorá zahŕňa jednotlivé alebo čiastočné subkompetencie, ale ktorá je len jedna a ktorá predstavuje repertoár disponibilný pre používatel'a jazykov. Táto revidovaná definícia tak väčšiu čast' jednotlivcov, ktorí sa doposial' definovali ako dvojjazyční, pretvára na jednotlivcov viacjazyčných. K definovaniu vlastného stavu plurilingvizmu vytvorila $\mathrm{J}$. Bírová (2016) prvotnú nerevidovanú sebahodnotiacu škálu, ktorá bola predstavená na národnej konferencii o jazykovom vzdelávaní pod záštitou ministra školstva, vedy, výskumu a športu a zároveň iniciatívy Európskej komisie v jazykovom vzdelávaní s názvom Európska značka pre jazyky 2015. Sebahodnotiaca škála sa má použit' skupine jednotlivcov, ktorí si zhodnotia svoje vedomosti a postoje a ktorí sa po sebahodnotení navzájom skonfrontujú prostredníctvom výšky skóre a grafov, ktoré si v skupinke zakreslia do pomocného materiálu.

\begin{tabular}{|l|l|c|c|c|}
\hline Viacjazyčný profil & $\begin{array}{l}\text { Body } \\
\text { max. }\end{array}$ & Ex. & $\begin{array}{l}\text { Moje } \\
\text { skóre }\end{array}$ \\
\hline $\mathbf{1}$ & $\begin{array}{l}\text { Každý deň sa zúčastňujem rozličných } \\
\text { komunikačných situácií s l'ud'mi v mojom okolí, } \\
\text { som komunikatívna osoba. }\end{array}$ & 6 & 4 & \\
\hline $\mathbf{2}$ & $\begin{array}{l}\text { Moja individuálna jazyková skúsenost' } \\
\text { vkultúrnom kontexte sa rozširuje od jazyka, } \\
\text { ktorý používam v rodine smerom k jazyku } \\
\text { spoločnosti a následne k jazykom iných } \\
\text { národov. Viem, že táto viacjazyčná } \\
\text { interkultúrna kompetencia buduje moju celkovú } \\
\text { komunikatívnu kompetenciu. }\end{array}$ & 2 & 2 & \\
\hline
\end{tabular}




\begin{tabular}{|c|c|c|}
\hline \multirow{2}{*}{$\begin{array}{l}\text { Ovládam a používam materinský jazyk }- \text { za } \\
\text { každú rečovú činnost' si pridel'te podl'a } \\
\text { vlastného uváženia a frekvencie prislúchajúci } \\
\text { počet bodov od } 0,25 \text { až po } 2 \text { body za činnost; } \\
\text { spolu maximálne } 18 \text { bodov (počúvanie } \\
\text { s porozumením (2), čítanie s porozumením (2), } \\
\text { audiovizuálna recepcia (2), súvislé rozprávanie } \\
\text { (2), ústne dialógy (2), písanie (2), písomná } \\
\text { interakcia (2), preklad, tlmočenie, rozličné } \\
\text { textotvorné operácie (4)) } \\
\text { Ovládam a používam jazyk z jazykovej vetvy } \\
\text { materinského jazyka ............................ jazyk - } \\
\text { za každú rečovú činnost si pridel'te podl'a } \\
\text { vlastného uváženia a frekvencie prislúchajúci } \\
\text { počet bodov od } 0,25 \text { až po } 2 \text { body za činnost'; } \\
\text { spolu maximálne } 18 \text { bodov (počúvanie } \\
\text { s porozumením, čítanie s porozumením, } \\
\text { audiovizuálna recepcia, súvislé rozprávanie, } \\
\text { ústne dialógy, písanie, písomná interakcia, } \\
\text { preklad, tlmočenie, rozličné textotvorné } \\
\text { operácie) }\end{array}$} & 18 & 15 \\
\hline & 18 & \\
\hline $\begin{array}{l}\text { Ovládam a používam jazyk z jazykovej vetvy } \\
\text { materinského jazyka ......................... jazyk - } \\
\text { za každú rečovú činnost' si pridel'te podl'a } \\
\text { vlastného uváženia a frekvencie prislúchajúci } \\
\text { počet bodov od } 0,25 \text { až po } 2 \text { body za činnost'; } \\
\text { spolu maximálne } 18 \text { bodov (počúvanie } \\
\text { s porozumením, čítanie s porozumením, } \\
\text { audiovizuálna recepcia, súvislé rozprávanie, } \\
\text { ústne dialógy, písanie, písomná interakcia, } \\
\text { preklad, tlmočenie, rozličné textotvorné } \\
\text { operácie) }\end{array}$ & 18 & $\begin{array}{c}\mathrm{CHJ} \\
4\end{array}$ \\
\hline
\end{tabular}

\begin{tabular}{|c|c|c|}
\hline $\begin{array}{l}\text { Ovládam a používam jazyk určitej } \\
\text { menšiny ........................... jazyk - za každú } \\
\text { rečovú činnost' si pridel'te podl'a vlastného } \\
\text { uváženia a frekvencie prislúchajúci počet } \\
\text { bodov od } 0,25 \text { až po } 2 \text { body za činnost'; spolu } \\
\text { maximálne } 18 \text { bodov (počúvanie } \\
\text { s porozumením, čítanie sporozumením, } \\
\text { audiovizuálna recepcia, súvislé rozprávanie, } \\
\text { ústne dialógy, písanie, písomná interakcia, } \\
\text { preklad, tlmočenie, rozličné textotvorné } \\
\text { operácie) }\end{array}$ & 18 & 0 \\
\hline $\begin{array}{l}\text { Ovládam a používam cudzí - ............................... } \\
\text { jazyk - za každú rečovú činnost' si pridel'te } \\
\text { podl'a vlastného uváženia a frekvencie } \\
\text { prislúchajúci počet bodov od } 0,25 \text { až po } 2 \text { body } \\
\text { za činnost'; spolu maximálne } 18 \text { bodov } \\
\text { (počúvanie s porozumením, crítanie } \\
\text { s porozumením, audiovizuálna recepcia, súvislé }\end{array}$ & 18 & $\begin{array}{l}\text { FJ } \\
15\end{array}$ \\
\hline
\end{tabular}




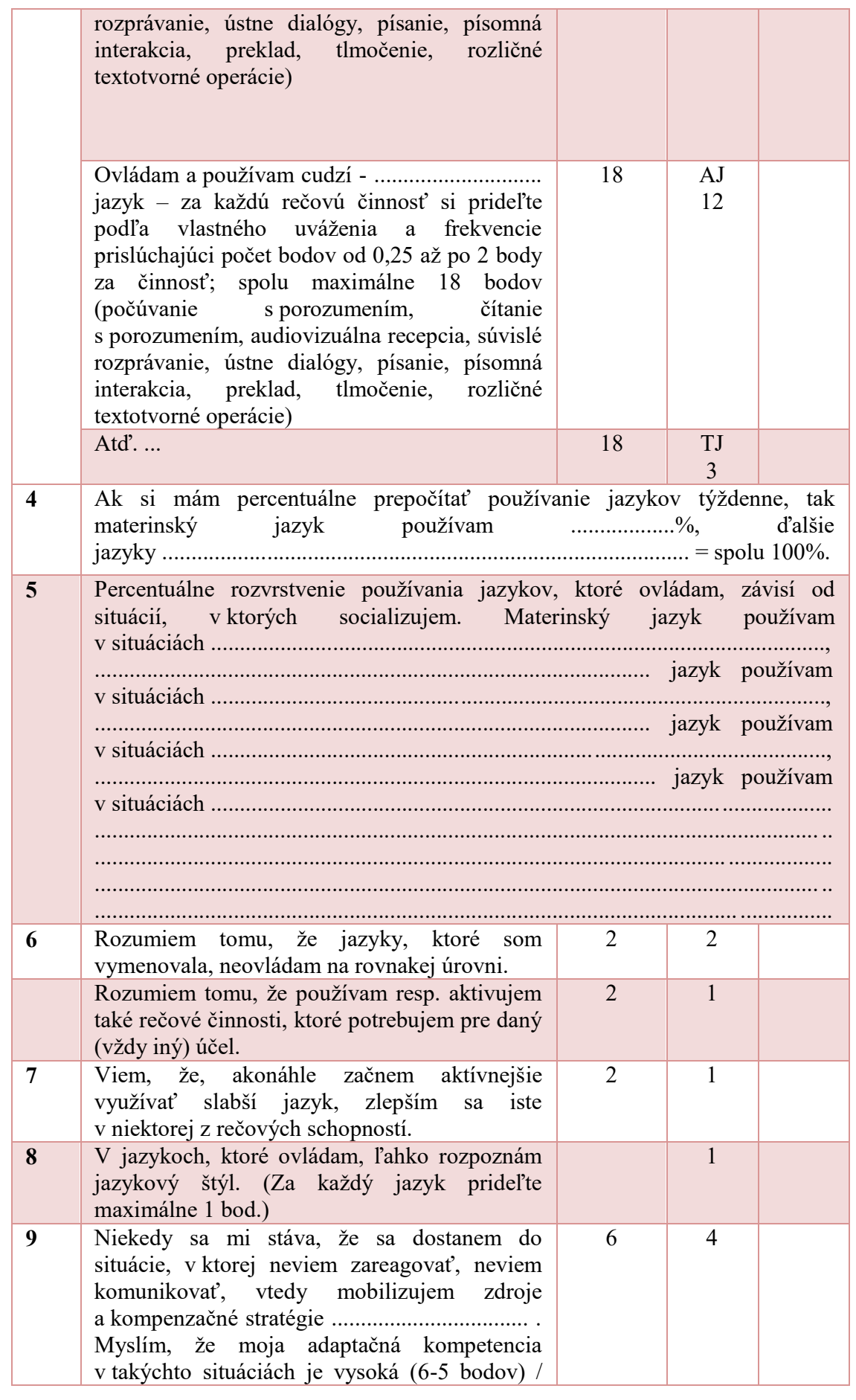

XLinguae Journal, Volume 9 Issue 2, April 2016, ISSN 1337-8384 


\begin{tabular}{|c|c|c|c|c|}
\hline & $\begin{array}{l}\text { priemerná ( } 4-3 \text { body) / nízka (2-1) / žiadna (0) / } \\
\text { neviem (N). }\end{array}$ & & & \\
\hline 10 & $\begin{array}{l}\text { Ak to mnohojazyčná situácia vyžaduje, v } \\
\text { komunikácii viem l'ahko prepínat' jazykové } \\
\text { kódy. }\end{array}$ & 5 & 1 & \\
\hline 11 & Iné & & & \\
\hline \multirow[t]{2}{*}{12} & Iné & & & \\
\hline & & & 73,5 & \\
\hline \multicolumn{5}{|c|}{ Spolu viacjazyčný profil } \\
\hline \multicolumn{2}{|c|}{ Plurikultúrny profil } & $\begin{array}{l}\text { Body } \\
\text { Max. }\end{array}$ & Ex. & $\begin{array}{l}\text { Moje } \\
\text { skóre }\end{array}$ \\
\hline 1 & $\begin{array}{l}\text { Poznám svoju dominantnú kultúru, svoje } \\
\text { subkultúry, alternatívne kultúry, kontrakultúru. }\end{array}$ & 3 & 2,5 & \\
\hline 2 & $\begin{array}{l}\text { Snažím sa byt' prínosom pre spoločnost' } \\
\text { a kultúry, v ktorých žijem. }\end{array}$ & 2 & 2 & \\
\hline \multirow[t]{8}{*}{3} & $\begin{array}{l}\text { Poznám kultúrne spoločenstvo svojho } \\
\text { materinského jazyka }\end{array}$ & 3 & 3 & \\
\hline & $\begin{array}{l}\text { Poznám } \\
\text { spoločenstvo ............................. jazyka (Resp. } \\
\text { Mám seriózne poznatky o kultúrnej komunite, } \\
\text { ktorej jazyk ovládam.) }\end{array}$ & 3 & $\begin{array}{l}\text { ČJ } \\
1,5\end{array}$ & \\
\hline & $\begin{array}{l}\text { Poznám } \\
\text { spoločenstvo .............................. jazyka (Resp. } \\
\text { Mám seriózne poznatky o kultúrnej komunite, } \\
\text { ktorej jazyk ovládam.) }\end{array}$ & 3 & $\begin{array}{l}\text { CHJ } \\
0,5\end{array}$ & \\
\hline & $\begin{array}{l}\text { Poznám kultúrne } \quad \text { spoločenstvo } \\
\text { menšiny ............................. jazyka (Resp. Mám } \\
\text { seriózne poznatky o kultúrnej komunite, ktorej } \\
\text { jazyk ovládam.) }\end{array}$ & 3 & $\begin{array}{c}\text { Róm.J } \\
2\end{array}$ & \\
\hline & $\begin{array}{l}\text { Poznám kultúrne } \quad \text { spoločenstvo } \\
\text { menšiny ............................. jazyka (Resp. Mám } \\
\text { seriózne poznatky o kultúrnej komunite, ktorej } \\
\text { jazyk ovládam.) }\end{array}$ & 3 & $\begin{array}{c}\text { Mad'.J } \\
1,5\end{array}$ & \\
\hline & $\begin{array}{l}\text { Poznám } \\
\text { spoločenstvo .............................. jazyka (Resp. } \\
\text { Mám seriózne poznatky o kultúrnej komunite, } \\
\text { ktorej jazyk ovládam.) }\end{array}$ & 3 & $\begin{array}{l}\text { FJ } \\
2,5\end{array}$ & \\
\hline & $\begin{array}{l}\text { Poznám } \\
\text { spoločenstvo .............................. jazyka (Resp. } \\
\text { Mám seriózne poznatky o kultúrnej komunite, } \\
\text { ktorej jazyk ovládam.) }\end{array}$ & 3 & $\begin{array}{l}\text { AJ } \\
1,5\end{array}$ & \\
\hline & $\begin{array}{l}\text { Poznám } \\
\text { spoločenstvo .............................. jazyka (Resp. } \\
\text { Mám seriózne poznatky o kultúrnej komunite, } \\
\text { ktorej jazyk ovládam.) }\end{array}$ & 3 & $\begin{array}{c}\text { TJ } \\
1\end{array}$ & \\
\hline
\end{tabular}




\begin{tabular}{|c|c|c|c|}
\hline & Atd'.... & & \\
\hline 4 & Ludí okolo seba rešpektujem takých, akí sú. & 3 & 2 \\
\hline 5 & $\begin{array}{l}\text { L’udí neposudzujem podl’a zovňajšku, } \\
\text { neposudzujem ani situácie bez kontextu. }\end{array}$ & 3 & 2 \\
\hline 6 & $\begin{array}{l}\text { Nediskriminujem ženy, mužov, slabších, } \\
\text { bielych, čiernych, deti, dospelých, } \\
\text { heterosexuálov, homosexuálov, krestanov, } \\
\text { židov, moslimov, podriadených. } \\
\text { Neprechovávam rasistické myšlienky. } \\
\begin{array}{l}\text { Neprechovávam extrémistické, etnocentrické } \\
\text { predstavy o živote a l'ud'och. }\end{array}\end{array}$ & 3 & 2,5 \\
\hline 7 & $\begin{array}{l}\text { Viem, aký/ á som, mám svoj svetonázor, ale } \\
\text { rešpektujem iných okolo seba a ich svetonázor. }\end{array}$ & 3 & 3 \\
\hline 8 & $\begin{array}{l}\text { Komunikačné a osobné problémy riešim } \\
\text { d'alšou, efektívnou, komunikáciou alebo činom. }\end{array}$ & 6 & 3 \\
\hline 9 & $\begin{array}{l}\text { Konflikty riešim asertívne s vedomím, že každý } \\
\text { konflikt alebo spor je možné vyriešit'. Kritický } \\
\text { interkultúrny moment (kultúrny šok) riešim so } \\
\text { snahou pochopit' príčinu konania iného. }\end{array}$ & 10 & 4 \\
\hline 10 & $\begin{array}{l}\text { Vnímam svoje hodnoty, ale rešpektujem } \\
\text { hodnoty iných. Tolerujem iných a ich inakost'. }\end{array}$ & 3 & 2,5 \\
\hline 11 & $\begin{array}{l}\text { Niekedy som ovplyvnený/ á hodnotami iných, } \\
\text { ktoré na mňa vplývajú pozitívne alebo } \\
\text { negatívne. Svoje hodnoty si chránim alebo } \\
\text { prispôsobujem, podl'a toho, ako ich } \\
\text { vyhodnotím. }\end{array}$ & 3 & 2,5 \\
\hline 12 & $\begin{array}{l}\text { Viem náležite a vhodne vyjadrit' svoj záporný } \\
\text { postoj v situácii, s ktorou nesúhlasím, alebo } \\
\text { ktorá ma obmedzuje, či márni moje hodnoty } \\
\text { a presvedčenia. }\end{array}$ & 3 & 1 \\
\hline 13 & $\begin{array}{l}\text { Akonáhle si vytvorím predstavu voči niekomu, } \\
\text { niečomu, nejakej situácii bez oboznámenia sa } \\
\text { o realite danej predstavy, predstava nevyústi } \\
\text { v predsudok. }\end{array}$ & 3 & 3 \\
\hline 14 & $\begin{array}{l}\text { Viem kontrolovat' svoje predsudky. Predsudky } \\
\text { nevyústia k stereotypným predstavám } \\
\text { o l'ud'och, národoch, veciach a situáciách. }\end{array}$ & 3 & 3 \\
\hline 15 & $\begin{array}{l}\text { Na l'udí vo svojom okolí sa snažím byt' milý/á. } \\
\text { Použivam milé slová, zdvorilostné slová } \\
\text { a politicky korektný jazyk. }\end{array}$ & 3 & 3 \\
\hline 16 & $\begin{array}{l}\text { Počas interkultúrnej komunikácie } \\
\text { priestor dávam } \\
\text { spolukomunikantovi. }\end{array}$ & 3 & 3 \\
\hline 17 & $\begin{array}{l}\text { Počas komunikácie s iným interkultúrne } \\
\text { bohatým človekom sa snažím udržat' kontakt } \\
\text { a ukončit' komunikačnú situáciu s úspechom } \\
\text { pre obidve komunikujúce strany. }\end{array}$ & 3 & 3 \\
\hline 18 & Iné & & \\
\hline
\end{tabular}

XLinguae Journal, Volume 9 Issue 2, April 2016, ISSN 1337-8384 


\begin{tabular}{|l|l|l|}
\hline $19 \quad$ Iné & & \\
\hline Spolu plurikultúrny profil & 52,5 & \\
\hline $\begin{array}{l}\text { TOTAL MOJE SKÓRE VIK (VIACJAZYČNÝ + } \\
\text { PLURIKULTÚRNY PROFIL) }\end{array}$ & & \\
\hline
\end{tabular}

\section{POROVNANIE SKÓRE V SKUPINE}

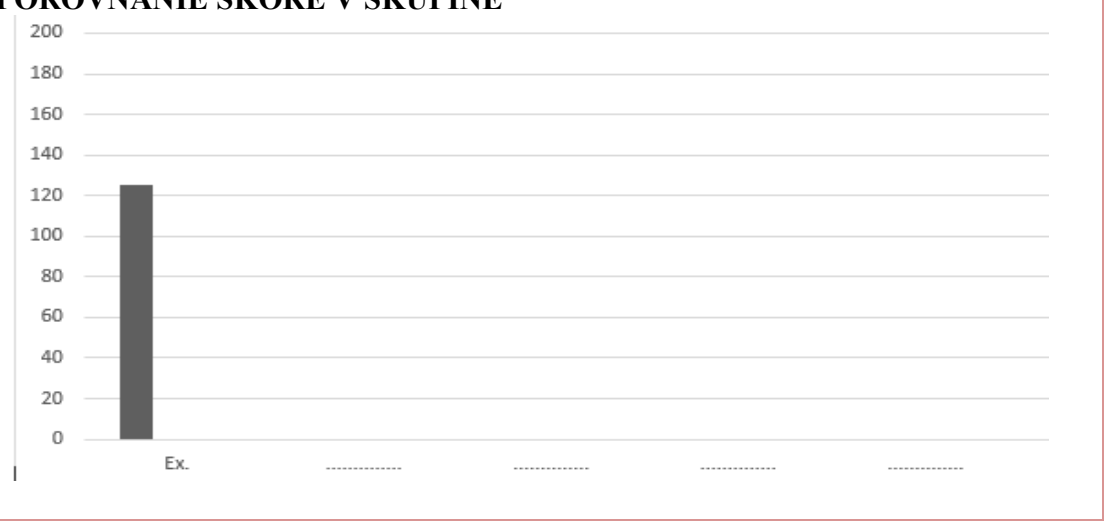

Zdroj: Bírová (2016)

\section{Bibliographic References}

APPEL, R. - MUYSKEN, P. 2005. Language Contact and Bilingualism. Amsterdam : Amsterdam University Press.

AYORA ESTEBAN, M. C. 2008. La situacion sociolinguistica en Ceuta: Un caso de lenguas en contacto. In Revista electronica de estudios filologicos, N. 16.

BAKER, C. - PRYS, J. 1998. Encyclopedia of Bilingualism and Bilingual Education. Multilingual Matters. 758 p. ISBN 13: 978-1853593628.

BERESOVA, J. 2013. Communicative Language Teaching: The Challenges of Its Implementation in Slovakia and a possible way forward. In International Scientific Publications: Language, Individual \& Society, Volume 7, Part 1. pp. 170-180, ISSN 1313-2547.

BERNAUS, M. - ANDRADE, A.-I. - KERVRAN, M. - MURKOWSKA, A. TRUJILlO SAEZ, F. 2007. Plurilingual and Pluricultural Awareness in Language Teacher Education. A training kit. Council of Europe. ISBN 978-92-871-6230-4.

BIALYSTOK, E. - CRAIK, F.I.M. - RYAN, J. 2006. Executive control in a modified antisaccade task: Effects of aging and bilingualism. In Journal of Experimental Psychology: Learning Memory and Cognition, 32 (6), pp. 1341-1354. ISSN 02787393. doi: 10.1037/0278-7393.32.6.1341

BIROVA, J. 2016. Pracovné hárky k hlavnej prednáške „Rozvoj plurilingvizmu na základných a stredných školách (Viacjazyčná interkultúrna kompetencia)” programu iniciatívy Európskej komisie v jazykovom vzdelávaní s názvom „Európska značka pre jazyky 2015“ organizovanej pod záštitou ministra školstva, vedy, výskumu a športu Slovenskej republiky 6. apríla 2016 v hoteli Mercure Bratislava. Bratislava: SAAIC Národná agentúra Programu Erasmus+ pre vzdelávanie a odbornú prípravu.

BIROVA, J. - ELIASOVA. 2014. Plurilingual and Pluricultural Competence and Foreign Language Teaching at Primary and Secondary Schools in Slovakia. In XLinguae. Vol. 7, no. 1, pp. 75-82. ISSN 1337-8384. 
BIROVA, J. 2013. About theoretical definitions of pluralistic and Pluricultural approaches. In XLinguae. Vol. 6, no. 2, pp. 91-103. ISSN 1337-8384.

BLOOMFIELD, L. 1933. Language. New York: Henry Holt and Company.

BYRAM, M. - MORGAN, C. et al. 1994. Teaching and Learning Language and Culture. Clevedon, Philadelphia: Multilingual Matters.

BYRAM, M. 1997. Teaching and Assessing Intercultural Communicative Competence. Clevedon, Philadelphia: Multilingual Matters.

CANDELIER, M. et al. 2011. Le CARAP, Un cadre de référence pour les approches plurielles des langues et des cultures. Graz: CELV, Conseil de l'Europe. Available online: http://carap.ecml.at.

COSTE, D. - MOORE, D. - ZARATE, G. 2009. Competence plurilingue et pluriculturelle. Strasbourg: Division des Politiques linguistiques.

CUKAN, J. - KORINA, N. - LENOVSKY, L. 2014. Culture - Language - Identity (problem of relations). In XLinguae European Scientific Language Journal. ISSN 1337-8384, 2014, Vol. 7, N. 4, pp. 21-32.

ETXEBARRIA AROSTEGUI, M. 2002. La diversidad de las lenguas en Espana. Madrid: Espasa.

FERGUSON, CH. 1959. Diglossia. In Word, N. 15, 1959, pp. 325-340.

GROMA, M. - TARCSIOVA, D. 1994. Vytvaranie podmienok pre uplatnenie bilingvalneho pristupu u nepocujucich Lit. 2 zazn. In: Efeta - otvor sa. Vol. 4, n. 3, pp. 8-9.

GROSJEAN, F. 2015. Bicultural bilinguals. In International Journal of Bilingualism, 19 (5), pp. 572-586. ISSN 1367-0069. doi: 10.1177/1367006914526297

GROSJEAN, F. 1982. Life with two languages: an introduction to bilingualism. Cambridge: Harvard University Press.

HAUGEN, E. 1956. Bilingualism in the Americas: A Bibliography and Research Guide. U. of Alabama Press.

MACKEY, W. 1962. "The description of bilingualism” in L. Wei. ED. Bilingualism Reader. UK: Routledge.

MACNAMARA, J. 1967. The bilingual's linguistic performance: A psychological overview. In Journal of Social Issues, 1967, Vol. 3, N. 2, pp. 58-77.

MORGENSTERNOVA, M. et al. 2011. Bilingvismus a interkulturni komunikace. Prague: Wolters Kluwer Czech Republic, a. s.

JANIKOVA, V. 2015. Learning Multiple Foreign Languages in Research: the Example of German (L3) after English (L2). In XLinguae, vol. 8 N. 2, April 2015. pp. 54-71. ISSN 1337-8384.

JESPERSEN, O. 1922. Language. London : George Allen and Unwin, 1922.

LAMBERT, W. E. 1983. Deciding on languages of instruction: psychological and social considerations. In Husen, T. \& Opper, S. (eds.). Multicultural and Multilingual Education in Immigrant Countries. Oxford: Pergamon Press.

LANCARIC, D. 2009. Krizene slova v anglictine. In Lingvistika a lingvodidaktika na skolach filologickeho zamerania 2. Bratislava: Z-F LINGUA. pp. 57-60. ISBN 97880-89328-28-4.

LEOPOLD, W. F. 1939. Speech Development of a Bilingual Child. Evanston: Northwestern University Press, 1939.

LIDDICOAT, A. 1991. Bilingualism: an introduction. In Liddicoat, A. (ed.). Bilingualism and Bilingual Education. Melbourne: National Languages Institute of Australia.

LOJOVA, G. et al. 2015. Deklarativne a proceduralne vedomosti vo vyucbe anglickeho jazyka. Bratislava: Comenius University.

LUPU, C. 2013. Linguistica Romanica. Bucuresti: Editura Universitatii din Bucuresti, $84 \mathrm{p}$. 
MALOVECKY, M. 2008. Analyza prirodzeneho jazyka a automatizacia. Bratislava: Univerzita Komenskeho. In Philologia 18. pp. 49-54

POKRIVCAKOVA, S. 2013. Bilingual Education in Slovakia: A Case Study. In Journal of Arts and Humanities, 2013, Vol. 7, no. 5 2013, pp. 10-19. ISSN 2167-9045. PEREZ, E. 2015. Translation and Subtitling of Documentary Films in Teaching Foreign Languages and Intercultural Communication. In XLinguae European Scientific Language Journal. ISSN 1337-8384, 2015, Vol. 8, N. 1 January, pp. 28-35.

PINTER, R. - KELLER, R. 1922. Intelligence tests for foreign children. In Journal of Educational Psychology, č. 13, pp. 1-23.

PRIOR, A. - MACWHINNEY, B. 2010. A bilingual advantage in task switching. In Bilingualism, 13 (2), pp. 253-262. ISSN 1366-7289. doi: 10.1017/S1366728909990526

REID. E. 2014. Status of Intercultural Education in English Language Learning and in Foreign Language Teacher Training [Miesto interkulturneho vzdelavania vo vyucovani anglickeho jazyka a v priprave ucitelov cudzich jazykov]. In XLinguae, vol. 7 N. 4, October 2014, pp. 43-54. ISSN 1337-8384.

SAER, D. 1923. The Effect of Bilingualism on Intelligence. In British Journal of Psychology, č. 14. pp. 25 - 38.

SANCHEZ CARRION, J. M. 1974. Bilinguismo, diglosia, contacto de lenguas. Hacia una delimitación de conceptos. In ASJU, 1974, pp. 3-79.

SERR. 2006. Spolocny europsky referencny ramec pre jazyky. Bratislava: SPU. ISBN 80-855756-93-5.

SHULLEY, L.J. - SHAKE, M.C. 2016. Investigating the relationship between bilingualism, cognitive control, and mind wandering. In Journal of Cognitive Psychology. Vol. 28, Issue 3, 2 April 2016, pp. 257-274.

SIGUAN, M. - MACKEY, W. F. 1986. Educacion y bilingüismo. Madrid: Santillana. SIGUAN, M. 1976. Bilingüismo y Sociologia. In R.E.L., pp. 27-88.

SINGH, L. - QUAM, C. 2016. Can bilingual children turn one language off? Evidence from perceptual switching. In Journal of Experimental Child Psychology. Volume 147, July 01, 2016, pp. 111-125. ISSN 0022-0965.

SINGER, R. M. 1987. Intercultural Communication: A Perceptual Approach. Englewood Cliffs, New Jersey: Prentice Hall, Inc.

STEFANIK, J. 2000. Bilingvizmus na pozadi dvoch morfologicky odlisnych typov jazykov. Intencny bilingvizmus u deti. Bratislava: Comenius University.

TRUJILLO, S.F. 2005. En tornoa la interculturalidad: Reflexiones sobre cultura y communicacion para la didactica de la lengua. In: Porta Linguarum 4. pp. 23-39.

VAJICKOVA, M. 2015. Theoretische Grundlagen stilistischer Textanalyse. Nümbrecht: Kirsch-Verlag.

VANCOVA, A. 2013. New perspectives of Special Education: Transfer of Knowledge in Neurosciences to Development and Innovation in Rehabilitationen, Corrective and Therapeutic Methods Based on Interdisciplinary Intervention with a Focus on Children with CNS Damage. In New perspectives in special education. Havlickuv Brod: Tobias. pp. 52-88. ISBN 978-80-7311-141-0.

VANCOVA, A. 2010. Analyza poziadaviek respondentov z beznych zakladnych a strednych skol na obsah vzdelavacich aktivit $\mathrm{v}$ oblasti deti a ziakov so specialnymi vychovno-vzdelavacimi potrebami. In Celozivotne vzdelavanie pedagogov v oblasti ziakov so specialnymi vychovno-vzdelavacimi potrebami. Bratislava: Iris, pp. 125167. ISBN 978-80-89238-44-6.

WEINREICH, U. 1953, 1979. Languages in contact: Findings and Problems. The Hague: Mouton Publishers.

WEINREICH, U. 1953b. Languages in Contact, Findings and Problems. The Hauge: Mouton. ISBN 13: 978-9027926890. 
Words: 4691

Characters: 35264 (19, 6 standard pages)

The study is the partial result of the project VEGA 1/0106/15 2015-2017 "Teoreticke skúmanie a empirické overenie konceptu interkultúrnej komunikativnej kompetencie ako súčasti aktuálnej koncepcie výučby ciel'ových jazykov v súčinnosti so Spoločným európskym referenčným rámcom pre jazyky: učenie, vyučovanie, hodnotenie".

doc. Mgr. Jana Bírová, PhD.

Mgr. Monika Barancová

Comenius University in Bratislava

Faculty of Education

Department of romance languagues and literatures

Račianska 59

81334 Bratislava

Slovakia

birova@fedu.uniba.sk

strokova1@fedu.uniba.sk

Mgr. Zuzana Šimková

Constantine the Philosopher University in Nitra

Faculty of Education

Department of Language Pedagogy and Intercultural Studies

Dražovská 2

94901 Nitra

Slovakia

zuzana.simkova@ukf.sk 